
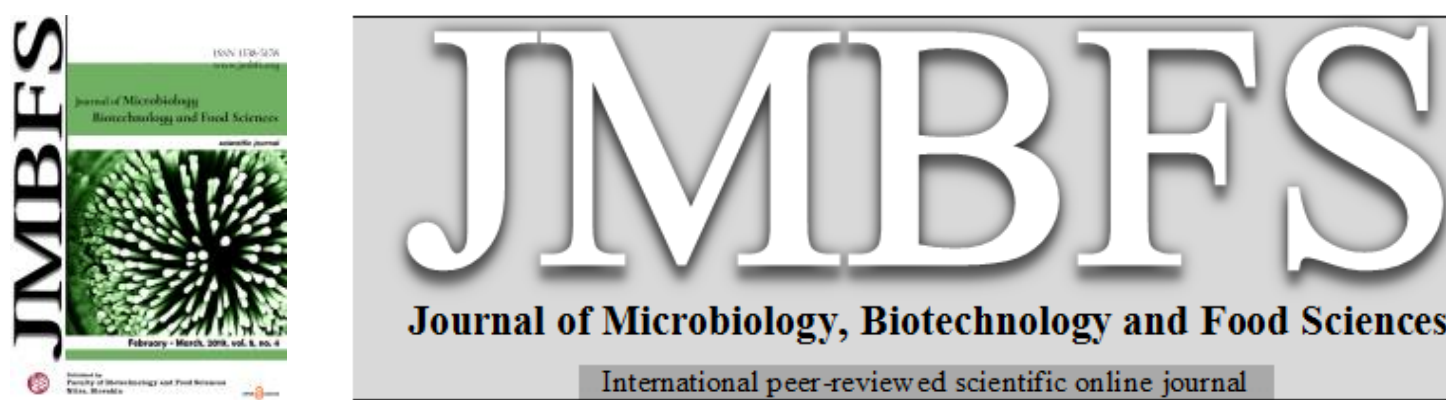

Journal of Microbiology, Biotechnology and Food Sciences

International peer-review ed scientific online journal

\title{
THE EFFECT OF RAW MATERIAL PRE MATURING ON PARENICA STEAMED CHEESE QUALITY
}

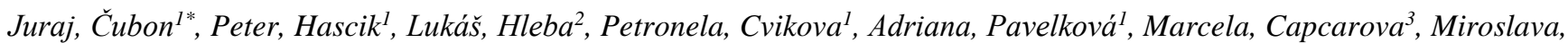 \\ Císarová ${ }^{5}$, Martina Ševelovát, Jana, Tkáčovál, Marek, Bobko ${ }^{1}$
}

Address(es): prof. Ing. Juraj Čuboň, CSc.,

${ }^{1}$ Slovak University of Agriculture in Nitra, Faculty of Biotechnology and Food Sciences, Department of Evaluation and Processing of Animal Products, Tr. A. Hlinku 2, 94976 Nitra, Slovakia.

${ }^{2}$ Slovak University of Agriculture in Nitra, Faculty of Biotechnology and Food Sciences, Department of Microbiology, Tr. A. Hlinku 2, 94976 Nitra, Slovakia.

${ }^{3}$ Slovak University of Agriculture in Nitra, Faculty of Biotechnology and Food Sciences, Department of Animal Physiology, Tr. A. Hlinku 2, 94976 Nitra, Slovakia.

${ }^{4}$ Slovak University of Agriculture in Nitra, Faculty of Biotechnology and Food Sciences, Department of Food Hygiene and Safety, Tr. A. Hlinku 2, 94976 Nitra, Slovakia.

${ }^{5}$ University of SS. Cyril and Methodius, Department of Biology, Faculty of Natural Sciences, Nám. J. Herdu 2, SK-91701 Trnava, Slovak Republic.

*Corresponding author: juraj.cubon@uniag.sk

doi: $10.15414 /$ jmbfs.2019.8.5.1231-1235

\section{ARTICLE INFO}

Received 14. 11. 2018

Revised 12. 12. 2018

Accepted 2. 1. 2019

Published 1. 4. 2019

Regular article open $\partial_{\text {Access }}$

\begin{abstract}
The aim of the present study was to analyse the quality of the Parenica cheese (steamed shaped cheese) made of cheese aged one and three weeks. MDA (malondialdehyde) contents were similar in both Parenica cheese ( $0.32 \mathrm{mg} . \mathrm{kg}^{-1}$ resp. $\left.0.30 \mathrm{mg} \cdot \mathrm{kg}^{-1}\right)$. Content of MDA was higher in the lump cheese-raw materials $\left(0.44\right.$ resp. $\left.0.59 \mathrm{mg} . \mathrm{kg}^{-1}\right)$ than in the Parenica cheese $\left(0.32 \mathrm{mg} \cdot \mathrm{kg}^{-1}\right.$ resp. $\left.0.30 \mathrm{mg} \cdot \mathrm{kg}^{-1}\right)$. MDA content can be probably reduced in the processing to the hot water. The concentration of tyramine in the lump cheese on the $1^{\text {st }}$ week of maturing was $1.37 \mathrm{mg} . \mathrm{kg}^{-1}$, and in the $3^{\text {rd }}$ week of maturing increased to $4.48 \mathrm{mg} . \mathrm{kg}^{1}$. Tyramine content in the Parenica cheese made from lump cheese after $1^{\text {st }}$ week of maturing was lower $\left(0.49 \mathrm{mg} \cdot \mathrm{kg}^{-1}\right)$ than the lump cheese after $3^{\text {rd }}$ week of maturing (2.47 $\left.\mathrm{mg} \cdot \mathrm{kg}^{-1}\right)$. The detected concentration of cadaverine was detected only in the lump cheese $3^{\text {rd }}$ week of maturing $\left(4.66 \mathrm{mg} \cdot \mathrm{kg}^{-1}\right)$ and in the Parenica cheese made from lump cheese after $3^{\text {rd }}$ week of maturing $\left(3.10 \mathrm{mg} \cdot \mathrm{kg}^{-1}\right)$. The sensory quality was performed by 5 points system. Parenica cheese made from lump cheese after $3^{\text {rd }}$ week of maturing (4.91 points) in comparison with Parenica cheese made from lump cheese after $1^{\text {st }}$ week of maturing (4.17 points). Overall acceptability was significantly higher for Parenica cheese made from lump cheese after $3^{\text {rd }}$ week of maturing (4.83 points) in comparison with Parenica cheese made from lump cheese after $1^{\text {st }}$ week of maturing ( 4.50 points). Higher sensorial quality of Parenica cheese made from lump cheese after $3^{\text {rd }}$ week of maturing was caused by longer time of maturing. The longer time of maturing positively affected all sensory and physico-chemical parameters, but biogenic amines (mainly cadaverine and tyramine) content increased, because of maturing.
\end{abstract}

Keywords: steamed cheese, physic-chemical properties, biogenic amines, sensory quality

\section{INTRODUCTION}

The Parenica cheese is a traditional Slovak product, same as Korbacik cheese, and is listed in the Regulation $(\mathbf{E U})$ No 1151/2012 on the protection of geographical indications and designations of origin for agricultural products and foodstuffs and belongs to the steamed cheese. In Slovak Republic steamed cheese production has long tradition. Steamed cheese is a special group of cheese whose production is typical for countries in the southern Europe, countries located on the Balkan Peninsula, Greece and Italy, which are generally called Pasta filata. Raw milk cheese represents a significant proportion of cheese in most Mediterranean countries, mainly those made from goat and ewe milk. To our knowledge, few studies have been made to compare cheese made from raw or pasteurized milk (Čuboň et al., 2015).

Number of studies analysed the influence of pasteurization on the cheese proteolysis, but mainly in the cow milk cheese (Rosenberg et al., 1995; Beuvier et al., 1997; Skeie \& Ardö, 2000). These studies have shown that there are little differences in consistency varieties of cheese, in relation to the influence of milk pasteurization on the primary and secondary proteolysis of cheese.

The level of acceleration the maturing process is possible to solve the problems of degradation of cheese quality. It is influenced by the intensity of proteolysis, contents of dry matter, fats, $\mathrm{NaCl}$ and $\mathrm{pH}$ level (Everard et al., 2006; Saint-Eve et al., 2009). The time of cheese ripening depends on the type of cheese. Current technologies of cheese production try to short the time of ripening (due to reduction of production costs) and consequently unripe cheese can be distributed to the networks. Their organoleptic parameters are different to the cheese qualities matured under standard conditions (Pachlová et al., 2011). Quality of milk, chemical composition (moisture, lactose, fat), using of proper starter lactic acid bacteria (SLAB) and presence of non-starter lactic acid bacteria (NSLAB) can also influence processes occurring in ripening cheese (Al-Otaibi and Wilbey, 2004; Floury et al., 2009; Pachlová et al., 2011).

Increasing of temperature for ripening process acceleration is regarded as the simplest technique from the technological points of view (Sihufe et al., 2010a). The intensive growth of both SLAB and NSLAB is important; can decrease the cheese quality because acceleration of other undesirable contaminating microorganisms can occur (Iurlina \& Fritz, 2004). Sihufe et al. (2010b) report possible double or triple decrease of ripening period by increase of ripening temperature by $6{ }^{\circ} \mathrm{C}$.

Cheese ripening represents a very important technological process, during which cheese undergoes important microbiological, biochemical and sensory changes. For consumers, texture plays a key role in cheese purchase. Changing of the cheese texture is mainly influenced by intensity of proteolysis, contents of $\mathrm{NaCl}$, dry matter and fats and by $\mathrm{pH}$ (Everard et al., 2006; Saint-Eve et al., 2009). Cheese texture and functional and sensory properties develop during the ripening process nevertheless traditional maturation is a costly process (Forde and Fitzgerald, 2000).

As reported Komprda et al. (2007); Buňková et al. (2010); Pachlová et al. (2011) the extent of microbiological and biochemical processes in individual parts of cheese might differ in individual cheese segments.

Steamed cheese is processed by hot water. The recommended lower limit water temperature is $70{ }^{\circ} \mathrm{C}$. The cheese is kneaded until to correct structure of matter suppleness, smoothness and elasticity. Recommended acidity of raw materials (lump cheese) for steamed cheese is 5.1 to $5.0 \mathrm{pH}$. Poorly fermented cheese is not enough elastic and it is not suitable to production of steamed cheese (Čuboň $\boldsymbol{e t}$ al., 2015). 
The moisture of Pasta filata cheese ranging between $47-52 \%$, protein 23.3 $25 . \%$, fat $18.5-25.1 \%$, salt $(\mathrm{NaCl}) 1.6-1.9 \%$ and $\mathrm{pH} 5.22-5.34$ (JimenezMaroto et al., 2016) .

The moisture of steamed Korbacik cheese ranging between $44.77-47.17 \%$, fat 22.07- $25.33 \%$, salt $(\mathrm{NaCl}) 0.38-0.39 \%$, acidity $98.27-108.33{ }^{\circ} \mathrm{SH}$ and MDA (malondialdehyde) content $0.37-0.59 \mathrm{mg} \cdot \mathrm{kg}^{-1}$ (Čuboň et al., 2015).

Parameters of the Slovak Parenica cheese takes the form of two interconnected coils of raw ribbon, $5-8 \mathrm{~cm}$ high with a diameter of $6-8 \mathrm{~cm}$. Traditionally, two rolls are fastened with a cheese string. Aroma of the Slovak Parenica cheese is a characteristic by the sheep milk and smoked. Taste is fine, salty a cheese with the seep milk odour. Consistency is elastic, with a supple structure and after ripping are threads formed. Colour is yellow to brown after smoking, inside white to butter yellow. Content of dry matter is at least 53\%; fat in dry matter at least 50\% and $\mathrm{NaCl}$ max. 3\%. It should contain NSLAB micro-organisms of the genus Lactobacillus, Enterococcus, Lactococcus and Streptococcus. It must not contain pathogenic microorganisms (Listeria Monocytogenes and Salmonella). By steaming at a temperature of $60-70{ }^{\circ} \mathrm{C}$ partial pasteurisation takes place which reduces the natural microflora content from $10^{5}$ to $10^{2}$ (Čuboň et al., 2015).

The food that contains proteins or free amino acids (FAA) and subjected to conditions enabling microbial or biochemical activity formation of biogenic amines (BA) can be expected. The total amount of the BA is variable and depending on the microorganisms involved and nature of food (Ruiz-Capillas $\boldsymbol{\&}$ Jimenez-Colmenero, 2004).

In the fact, during cheese ripening, there is a breaking down of caseins, which leads to an accumulation of FAA that can be transformed into BA by the decarboxylase activity of the present microbiota (Sihufe et al., 2010).

However, it is difficult to find a straight correlation between microbial counts and BA content in cheese, because of BA producing abilities of various strains of different bacteria differ widely (Linares et al., 2011). Moreover several external processing factors may also play an important role, namely, milk pasteurization, $\mathrm{pH}$ value, salt in moisture contents and temperature of ripening. In particular, the cheese $\mathrm{pH}$ within the range 5.0-6.5 is optimum for the activity of most decarboxylases and it has been found that the production of biogenic amines is accelerated by high temperatures during production, cheese manufacture and by the prolonged process of aging (Buňková et al., 2010). Butor et al. (2017) identified biogenic amine (tryptamine, $\beta$-phenylethylamine, putrescine, cadaverine, histamine and tyramine) by MALDI-TOF MS device. Flasarová $\boldsymbol{e}$ al. (2016) found out the total biogenic amine content $0.4 \mathrm{mg} . \mathrm{L}^{-1}$ in the milk before cheese production.

Most of the products fermented by lactic acid bacteria (LAB) contain traces of cadaverine, histamine, putrescine, and tyramine (Spano et al., 2010; Linares et al., 2011).

Under normal conditions, biogenic amines in the digestive system are inactivated and there are no clinical cause of the disease. In the case of large amount intake of biogenic amines the inactivation mechanisms are degraded, they get out of the digestive system (Čuboň et al., 2019).

Nedomová et al. (2017) found out lightness of fresh cheese ( $\left.L^{*}\right)$ 89.56, green-red value $\left(a^{*}\right) 0.52$ and blue-yellow value $\left(b^{*}\right) 15.83$ and after ripening it changed as follows $\mathrm{L}^{*} 85.91, \mathrm{a}^{*} 0.51$ and $\mathrm{b} * 18.62$.

The aim of the present study was to analyse the quality of the Parenica cheese (steamed shaped cheese) made of cheese aged 1 and 3 weeks.

\section{MATERIALS AND METHODS}

\section{Cheese Samples}

Ripened lump cheese after 1 and 3 weeks of ripening was used as raw material for the production of Parenica cheese. The Parenica cheese was produced after $1^{\mathrm{s}}$ week $(n=10)$ and $3^{\text {rd }}$ week $(n=10)$ of ripening from lump cheese. The cheese was heated to a temperature of $60-70 \mathrm{C}^{\circ}$ to mouldable consistency. Subsequently, the formed strip with a width of 5-6 cm, in saline salted and rolled into Parenica cheese a diameter of 6-8 $\mathrm{cm}$ was used.

The Parenica cheese is protected by geographical indication and designations of origin for agricultural products and foodstuffs. Parenica cheese is a steamed cheese made from lump cheese contains especially thermotolerant lactic acio microflora of the genera: Lactococcus, Streptococcus and Lactobacillus. Chemical requirements: dry matter at least $53 \%$. Fat in dry matter content at least 50\%, salt content max. $3.0 \%$. Microbiological characteristics: raw material for Parenica cheese is the lump cheese, which contains mainly genera Lactococcus, Lactobacillus and Streptococcus - thermoresistant lactic acid microflora. It must not contain pathogenic microorganisms (e. g. Listeria monocytogenes and Salmonella). Steaming at temperature $60-70^{\circ} \mathrm{C}$ results partial pasteurisation, which reduces the natural microflora content from the $10^{5}$ to $10^{2} \mathrm{CFU}_{\mathrm{g}} \mathrm{g}^{-1}$ (Regulation (EU) No 1151/2012; Commission Regulation (EC) No. 2073/2005).

\section{Chemical composition analysis}

The chemical composition of the raw material (ripened lump cheese) and Parenica cheese was measured $(50 \mathrm{~g})$ by the FT IR method using the device
Nicolet 6700 (Thermo Scientific, USA). The fat contents (g. $\left.100 \mathrm{~g}^{-1}\right)$ and moisture content $\left(\mathrm{g} .100 \mathrm{~g}^{-1}\right)$ were analysed. The infra-red analyse was carried out by the molecular spectroscopy method.

Contents of salt $\left(\mathrm{g} .100 \mathrm{~g}^{-1}\right)$, and titration acidity $\left({ }^{\circ} \mathrm{SH}\right)$ was analysed according to Čuboň et al. (2015).

\section{Determination of malondialdehyde}

The degradation products of Parenica cheese were analysed. Malondialdehyde (MDA) content was measured in the Parenica cheese. MDA content was determined according to Marcinčák $\boldsymbol{e t}$ al. (2006). Absorbance of samples was measured at a wavelength of $532 \mathrm{~nm}$ on UV-VIS spectrophotometer Jenway 7305 (United Kingdom -JENWAY). Results were calculated as the mg of MDA in $1 \mathrm{~kg}$ of sample $\left(\mathrm{mg} \cdot \mathrm{kg}^{-1}\right)$.

\section{Determination of biogenic amines contents}

The collected samples were homogenised, and subsequently lyophilised (Christ Alpha 1-4 device, Christ, Germany, Osterode am Harz). The amines were extracted with a perchloric acid solution $\left(0.6 \mathrm{mpl} . \mathrm{L}^{-1}\right)$ in triplicate. The content of biogenic amines was determined by liquid chromatography (LabAlliance and Agilent Technologies devices) after previous derivatisation with dansylchloride. Chromatographic separation (column used: ZORBAX Eclipse XDB-C18, $150 \times 4.6 \mathrm{~mm}, 3.5 \mu \mathrm{m}$, Agilent Technologies, Inc., Santa Clara, CA, USA) and spectrophotometric detection $(\lambda=254 \mathrm{~nm})$ were performed according to Buňková et al. (2013). Each sample was extracted in triplicate, each extract was derivatised in duplicate and each derivatised mixture was applied on the column in triplicate. In individual amines, the detection limits ranged between 0.24 and $1.39 \mathrm{mg} \cdot \mathrm{kg}^{-1}$. The results were related to the sample weight before lyophilisation.

\section{Sensory analysis}

The sensory characteristics were evaluated in sensory analysis: aroma and taste, consistency, colour and total appearance. Sensory analysis was performed using the sensory evaluation using scale. A five-point scale was used to the characteristics of each point. Assessment system was chosen, the highest number of points (5) was evaluated as ,excellent” and 1 point as „unacceptable”. In the sensory committee were 5 assessors.

\section{Statistical analyse}

The data were subjected to statistical analysis using the Statistic Analysis System (SAS) package (SAS 9.3 using of application Enterprise Guide 4.2) by nonparametric Wilcoxon test.

\section{RESULTS AND DISCUSSION}

Table 1 shows basic physicochemical parameters of fresh lamb cheese, lamb cheese after $1^{\text {st }}$ and $3^{\text {rd }}$ week of maturing. Humidity of the fresh lump cheese was 44.56 g. $100 \mathrm{~g}^{-1}$. Lump cheese after $1^{\text {st }}$ week of maturing was $44.77 \%$ and lump cheese after $3^{\text {rd }}$ week of maturing was $45.17 \mathrm{~g} \cdot 100 \mathrm{~g}^{-1}$. The measured values of humidity for all samples were similar. The dry matter content in the fresh cheese

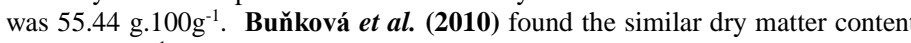

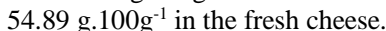

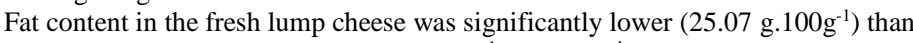
in the $1^{\text {st }}$ week of maturing $\left(25.33 \mathrm{~g} .100 \mathrm{~g}^{-1}\right)$ and at $3^{\text {rd }}$ weeks of maturing 25.66 g. $100 \mathrm{~g}^{-1}$. Same tendency was in the content of fat in the dry matter. Titration acidity increased with maturing stage of cheese, $88.32^{\circ} \mathrm{SH}$ in the fresh cheese, $98.27^{\circ} \mathrm{SH}$ in the cheese after $1^{\text {st }}$ week of maturing and $108.32^{\circ} \mathrm{SH}$ in the cheese after $3^{\text {rd }}$ weeks of maturing. Malondialdehyde (MDA) content as a parameter of the oxidative stability was significantly lowest in the fresh lump cheese $(0.37$ $\left.\mathrm{mg} \cdot \mathrm{kg}^{-1}\right)$ and the highest in the cheese after $3^{\text {rd }}$ weeks of maturing $\left(0.59 \mathrm{mg} \cdot \mathrm{kg}^{-1}\right)$ The different results were found by Jimenez-Maroto et al. (2016), who found out in the fresh lump cheese higher humidity content $\left(53.8 \mathrm{~g}^{1} 100 \mathrm{~g}^{-1}\right)$ and lower fat content $\left(16.6 \mathrm{~g} .100 \mathrm{~g}^{-1}\right)$

Humidity of the Parenica cheese (Table 2) made from lump cheese after $1^{\text {st }}$ week of maturing was significantly lower $\left(44.90 \mathrm{~g}^{-100 \mathrm{~g}^{-1}}\right)$ than Parenica from lump cheese after $3^{\text {rd }}$ week of maturing $\left(53.07 \mathrm{~g}^{2} 100 \mathrm{~g}^{-1}\right)$. Kirmaci (2016) found

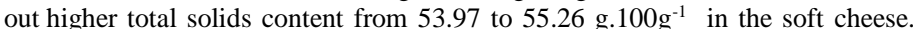
Average of fat contents was $22.50 \mathrm{~g} .100 \mathrm{~g}^{-1}\left(1^{\text {st }}\right.$ week $)$ and $20.13 \mathrm{~g} .100 \mathrm{~g}^{-1}\left(3^{\text {rd }}\right.$ week). Fat content in the dry matter was higher at the $1^{\text {st }}$ week $(40.83 \%)$ than after $3^{\text {rd }}$ week 42.91 g. $100 \mathrm{~g}^{-1}$. Sodium chloride content was $1.82 \mathrm{~g} .100 \mathrm{~g}^{-1}\left(1^{\mathrm{st}}\right.$ week) and $1.58 \%$ ( $3^{\text {rd }}$ week) of maturing. Average titration acidity of Parenica cheese at $1^{\text {st }}$ week of maturing $\left(99.73^{\circ} \mathrm{SH}\right)$ was significantly lower than $3^{\text {rd }}$ week of maturing $\left(109.53^{\circ} \mathrm{SH}\right)$

MDA contents were similar in the both Parenica cheese $\left(0.32 \mathrm{mg} . \mathrm{kg}^{-1}\right.$ resp. 0.30 $\left.\mathrm{mg} \cdot \mathrm{kg}^{-1}\right)$.

Jimenez-Maroto et al. (2016) found out in the steamed type of cheese lower humidity content $\left(52.0 \mathrm{~g} .100 \mathrm{~g}^{-1}\right)$ and lower fat content $\left(18 \mathrm{~g} .100 \mathrm{~g}^{-1}\right)$. 
MDA content was significantly higher in the lump cheese $(0.44$ resp. $0.59 \mathrm{mg} . \mathrm{kg}$ $\left.{ }^{1}\right)$ than in the Parenica cheese $\left(0.32 \mathrm{mg} \cdot \mathrm{kg}^{-1}\right.$ resp. $\left.0.30 \mathrm{mg} \cdot \mathrm{kg}^{-1}\right)$. MDA content can be reduced in the processing to the hot water, because according to Nair $\boldsymbol{e t}$ al. (2008) malondialdehyde is soluble in the water.

Table 1 Physicochemical parameters of raw materials (lump cheese) at different ripening time

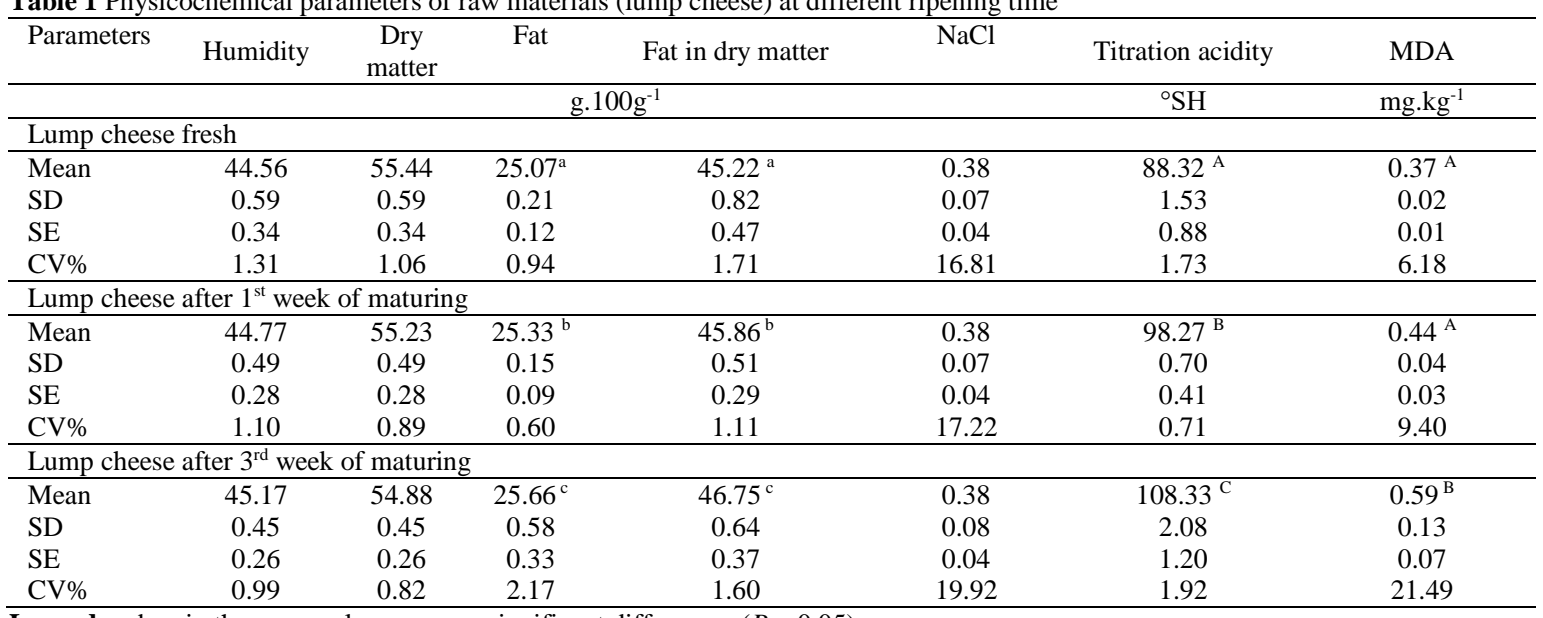

Legend: $\mathrm{a}, \mathrm{b}, \mathrm{c}$ in the same column means significant differences $(P<0.05)$.

$\mathrm{A}, \mathrm{B}, \mathrm{C}$ in the same column means significant differences $(P<0.01)$.

Table 2 Physicochemical parameters of Parenica cheese

\begin{tabular}{|c|c|c|c|c|c|c|c|}
\hline Parameters & Humidity & Dry matter & Fat & $\begin{array}{c}\text { Fat in dry } \\
\text { matter }\end{array}$ & $\mathrm{NaCl}$ & $\begin{array}{c}\text { Titration } \\
\text { acidity }\end{array}$ & MDA \\
\hline & & & $\%$ & & & ${ }^{\circ} \mathrm{SH}$ & $\left(\mathrm{mg} \cdot \mathrm{kg}^{-1}\right)$ \\
\hline \multicolumn{8}{|c|}{ Parenica cheese made from lump cheese after $1^{\text {st }}$ week of maturing } \\
\hline SD & 1.39 & 1.39 & 1.32 & 2.18 & 0.42 & 2.05 & 0.06 \\
\hline SE & 0.80 & 0.80 & 0.76 & 1.26 & 0.24 & 1.19 & 0,03 \\
\hline $\mathrm{CV} \%$ & 3.09 & 2.52 & 5.88 & 5.34 & 23.08 & 2.06 & 17.67 \\
\hline Mean & 53.07 & 46.93 & 20.13 & 42.91 & 1.58 & 109.53 & 0.30 \\
\hline SD & 0.50 & 0.50 & 1.27 & 3.00 & 0.28 & 3.14 & 0.00 \\
\hline SE & 0.29 & 0.29 & 0.73 & 1.73 & 0.16 & 1.81 & 0.00 \\
\hline CV\% & 0.94 & 1.07 & 6.29 & 6.99 & 17.96 & 2.87 & 1.17 \\
\hline
\end{tabular}

Legend: MDA - Malondialdehyde

Table 3 The content of biogenic amines in lump cheese maturing 1 and 3 weeks and Parenica cheese made of cheese aged 1 and 3 weeks $\underline{\left(\mathrm{mg} . \mathrm{kg}^{-1}\right)}$

\begin{tabular}{|c|c|c|c|c|c|}
\hline \multirow{2}{*}{ Parameters } & & \multicolumn{4}{|c|}{ Biogenic amines } \\
\hline & & putrescine & cadaverine & histamine & tyramine \\
\hline \multirow{4}{*}{$\begin{array}{l}\text { Lump cheese after } 1^{\text {st }} \text { week of } \\
\text { maturing }\end{array}$} & Mean & ND & ND & ND & $1.37^{\mathrm{a}}$ \\
\hline & $\mathrm{SD}$ & - & - & - & 0.30 \\
\hline & SE & - & - & - & 0.06 \\
\hline & $\mathrm{CV} \%$ & - & - & - & 14.59 \\
\hline \multirow{4}{*}{$\begin{array}{l}\text { Lump cheese after } 3^{\text {rd }} \text { week of } \\
\text { maturing }\end{array}$} & Mean & $4.60^{\mathrm{a}}$ & $4.66^{\mathrm{a}}$ & ND & $4.48^{\mathrm{b}}$ \\
\hline & $\mathrm{SD}$ & 0.52 & 0.51 & - & 0.64 \\
\hline & SE & 0.27 & 0.10 & - & 0.10 \\
\hline & $\mathrm{CV} \%$ & 23.08 & 10.41 & - & 11.49 \\
\hline \multirow{4}{*}{$\begin{array}{l}\text { Parenica cheese made from } \\
\text { lump cheese after } 1^{\text {st }} \text { week of } \\
\text { maturing }\end{array}$} & Mean & ND & ND & ND & $0.49^{\mathrm{c}}$ \\
\hline & SD & - & - & - & 0.08 \\
\hline & SE & - & - & - & 0.01 \\
\hline & $\mathrm{CV} \%$ & - & - & - & 18.07 \\
\hline \multirow{4}{*}{$\begin{array}{l}\text { Parenica cheese made from } \\
\text { lump cheese after } 3^{\text {rd }} \text { week of } \\
\text { maturing }\end{array}$} & Mean & $2.01^{\mathrm{b}}$ & $3.10^{\mathrm{b}}$ & 0.40 & $2.47^{\mathrm{d}}$ \\
\hline & $\mathrm{SD}$ & 0.74 & 0.78 & 0.04 & 0.34 \\
\hline & SE & 0.17 & 0.14 & 0.02 & 0.08 \\
\hline & $\mathrm{CV} \%$ & 37.12 & 25.14 & 7.21 & 13.93 \\
\hline
\end{tabular}

Legend: $a, b, c, d$ in the same column means significant differences $(P<0.05)$, ND - not detected

The concentration of tyramine contents (Table 3 ) in the lump cheese on the $1^{\text {st }}$ week of maturing was $1.37 \mathrm{mg} \cdot \mathrm{kg}^{-1}$, and on the $3^{\text {rd }}$ week of maturing increased to $4.48 \mathrm{mg} \cdot \mathrm{kg}^{-1}$.

Tyramine content in the Parenica cheese made from lump cheese after $1^{\text {st }}$ week of maturing was lower $\left(0.49 \mathrm{mg} \cdot \mathrm{kg}^{-1}\right)$ than the lump cheese after $3^{\text {rd }}$ week of maturing $\left(2.47 \mathrm{mg} \cdot \mathrm{kg}^{-1}\right)$.

The detected concentration of cadaverine was only in the lump cheese after $3^{\text {rd }}$ week of maturing (4.66 mg. $\left.\mathrm{kg}^{-1}\right)$ and in the Parenica cheese made from lump cheese after $3^{\text {rd }}$ week of maturing $\left(3.10 \mathrm{mg}^{\mathrm{kg}} \mathrm{kg}^{-1}\right)$.

The same tendency was in the putrescine content which was detected only in the lump cheese after $3^{\text {rd }}$ week of maturing $\left(4.60 \mathrm{mg} \cdot \mathrm{kg}^{-1}\right)$ and in the Parenica cheese made from lamb cheese after $3^{\text {rd }}$ week of maturing $\left(2.01 \mathrm{mg} \cdot \mathrm{kg}^{-1}\right)$. Buňková $\boldsymbol{e t}$ al. (2013) found out content of putrescine $20.7 \mathrm{mg} \cdot \mathrm{kg}^{-1}$ and content of cadaverine $19.6 \mathrm{mg} \cdot \mathrm{kg}^{-1}$ in the fresh cheese and authors did not detected cadaverine, putrescine, tyramine and histamine in the Pasta filata type of cheese.
The highest cadaverine contents $20.1 \mathrm{mg} \cdot \mathrm{kg}^{-1}$ in the cheese matured short time found out Buňka et al. (2012). Biogenic amines are products of metabolism of many microorganisms, so they can be used as spoilage indicators of food rich in proteins. According to Flasarová et al. (2016) the presence of non-starter and starters lactobacilli in the cheese can have effect on the biogenic amine content. The concentration of biogenic amines can be influenced by the technology of steamed cheese production because biogenic amines are water-soluble (Lide and David, 2007). Pachlová et al. (2018) found out content of biogenic amines in cheeses with using of $L b$. paracease DEPE T52 contents of tyramine at $30^{\text {th }}$ day was $20.6 \mathrm{mg} \cdot \mathrm{kg}^{-1}$.

Pachlová et al. (2013) found out total biogenic amine content in ripened cheese $140 \mathrm{mg} \cdot \mathrm{kg}^{-1}$. According to Buňka et al. (2012) the thyramine content increased in the cheese from the $10.7 \mathrm{mg} \cdot \mathrm{kg}^{-1}$ (at the beginning of the storage) to the 140.6 mg. $\mathrm{kg}^{-1}$ at the $19^{\text {th }}$ days of the storage. Content of free amino acids in the 
traditional Kashkaval cheese increased from $73.10 \mathrm{mg} \cdot 100 \mathrm{~g}^{-1} 5^{\text {th }}$ day to 87.50 mg. $100 \mathrm{~g}^{-1} 15^{\text {th }}$ day of maturing Dimitrov et al. (2015).

The sensory quality was analysed by Sensory descriptors and was defined from the appearance, aroma, flavor and texture evaluation by commission. Sensory evaluation was performed by 5 points system. The sensory parameters of Parenica cheese are shown in Table 4. Taste evaluation shows significantly better score $(P<0.05)$ for Parenica cheese made from lump cheese after $3^{\text {rd }}$ week of maturing 4.91 points in comparison with Parenica cheese made from lump cheese after $1^{\text {st }}$ week of maturing 4.17 points. Overall acceptability was significantly higher in Parenica cheese made from lump cheese after $3^{\text {rd }}$ week of maturing 4.83 points in comparison with Parenica cheese made from lump cheese after $1^{\text {st }}$ week of maturing 4.50 points.

\begin{tabular}{|c|c|c|c|c|c|}
\hline Parameters & Odour & Taste & Texture & Colour & $\begin{array}{c}\text { Overall } \\
\text { acceptability }\end{array}$ \\
\hline \multicolumn{6}{|c|}{ Parenica cheese made from lump cheese after $1^{\text {st }}$ week of maturing } \\
\hline Mean & 4.58 & $4.17^{\mathrm{a}}$ & 4.75 & 4.83 & $4.50^{\mathrm{a}}$ \\
\hline SD & 0.32 & 0.29 & 0.60 & 0.29 & 0.31 \\
\hline SE & 0.19 & 0.17 & 0.34 & 0.17 & 0.18 \\
\hline $\mathrm{CV} \%$ & 7.62 & 6.93 & 12.86 & 5.97 & 7.48 \\
\hline \multicolumn{6}{|c|}{ Parenica cheese made from lump cheese after $3^{\text {rd }}$ week of maturing } \\
\hline Mean & 4.67 & $4.91^{\mathrm{b}}$ & 4.83 & 4.91 & $4.83^{\mathrm{b}}$ \\
\hline SD & 0.58 & 0.30 & 0.29 & 0.30 & 0.29 \\
\hline SE & 0.33 & 0.17 & 0.17 & 0.17 & 0.17 \\
\hline $\mathrm{CV} \%$ & 12.37 & 6.08 & 5.97 & 6.08 & 5.97 \\
\hline
\end{tabular}

Legend: $\mathrm{a}, \mathrm{b}$ in the same column means significant differences $(P<0.05)$

The texture analyses showed non-significantly higher evaluation of Parenica cheese made from lump cheese after $3^{\text {rd }}$ week of maturing (4.83 points) in comparison with Parenica cheese after $1^{\text {st }}$ week of maturing (4.75 points). The same results were achieved in odour evaluation.

Higher sensorial quality of Parenica cheese made from lump cheese after $3^{\text {rd }}$ week of maturing was caused by longer time of maturing.

Consistently with our results Jimenez-Maroto et al. (2016) found that in steamed cheese Pasta filata was the highest evaluated taste profile and consistency. The best flavour rating was for cheese with salt contents of 1.8 $1.9 \%$. The same results were in our samples of Parenica cheese made from lump cheese after $1^{\text {st }}$ week of maturing. The higher value of consistency was in cheese with fat content of $23.9-25.1 \%$.

In our previous work we found out similar value for taste in Korbacik cheese (steamed cheese) made from raw materials ripened 1 week (4.33 points) and Korbacik cheese made from raw materials ripened 3 weeks (5.00 points) (Čubon̆ et al., 2015). Average point numbers for colour was 4.67 points for Korbacik cheese made from raw materials ripened 1 week and 4.83 points for Korbacik cheese made from raw materials ripened 3 weeks. Overall acceptability of Korbacik cheese made from raw materials ripened 1 week was 3.83 and Korbacik cheese made from raw materials ripened 3 weeks was 4.83 .

Romeih et al. (2002) evaluated steamed cheese by 7 points method and they found appearance 5.8 points, flavour 4.9 , consistency 3.7 and odour 4.8 points.

\section{CONCLUSION}

The analysed traditional Slovak steamed-formed Parenica cheese was made from lump cheese which was 1 and 3 weeks matured. However, traditionally Parenica cheese is made from fresh lump cheese that matures several days. The longer time of maturing positively affected sensory parameters. Steaming process in hot water resulted in decreasing of biogenic amines content. The lower dry mater content in the Parenica cheese made from lump cheese after $3^{\text {rd }}$ week of maturing was influenced by maturing process. The longer time of maturing positively affected all sensory and physico-chemical parameters. On the other hand, biogenic amines content increased, mainly cadaverine and tyramine.

The concentration of the malondialdehyde and biogenic amines can be leached into the water during the technology of steamed cheese production, because biogenic amines are water-soluble.

Acknowledgments: This work was supported by the KEGA no. 027SPU-4/2019

\section{REFERENCES}

Al-Otaibi, M. M., \& Wilbey, R. A. 2004. Effect of temperature and salt on the maturation of white-salted cheese. International journal of dairy technology, 57(1), 57-63. https://doi.org/10.1111/j.1471-0307.2004.00123.x

Beuvier, E., Berthaud, K., Cegarra, S., Dasen, A., Pochet, S., Buchin, S., \& Duboz, G. 1997. Ripening and quality of Swiss-type cheese made from raw, pasteurized or microfiltered milk. International Dairy Journal, 7(5), 311-323. https://doi.org/10.1016/s0958-6946(97)00015-0

Buňková, L., Adamcová, G., Hudcová, K., Velichová, H., Pachlová, V., Lorencová, E., \& Buňka, F. 2013. Monitoring of biogenic amines in cheese manufactured at small-scale farms and in fermented dairy products in the Czech Republic. Food chemistry, 141(1), 548-551. https://doi.org/10.1016/j.foodchem.2013.03.036

Buňková, L., Buňka, F., Mantlová, G., Čablová, A., Sedláček, I., Švec, P. \& Kráčmar, S. 2010. The effect of ripening and storage conditions on the distribution of tyramine, putrescine and cadaverine in Edam-cheese. Food microbiology, 27(7), 880-888. https://doi.org/10.1016/j.fm.2010.04.014

Buňka, F., Zálesáková, L., Flasarová, R., Pachlová, V., Budinský, P., \& Buňková, L. 2012. Biogenic amines content in selected commercial fermented products of animal origin. The Journal of Microbiology, Biotechnology and Food Sciences, 2(1), 209-218.

Butor, I., Pištěková, H., Purevdorj, K., Jančová, P., Buňka, F., \& Buňková, L. 2017. Biogenic amines degradation by microorganisms isolated from cheese Potravinarstvo Slovak Journal of Food Sciences, 11(1), 302-308 https://doi.org/10.5219/736

Commission Regulation (EC) No. 2073/2005 of 15 November 2005 on Microbiological Criteria for Foodstuffs. (2005).

Čuboň, J., Kunová, S., Kačániová, M., Haščík, P., Bobko, M., Bučko, O., Petrová, J., Cviková, P. 2015. Quality evaluation of Korbačik cheese. Potravinarstvo Slovak Journal of Food Sciences, 9 (1), 523-529. https://doi.org/10.5219/549

Čuboň, J., Cviková, P., Haščík, P., Kačániová, M., Kunová, S., Hleba, L., Bobko, M., Trembecká L., Bučko, O. \& TKÁČOVÁ J. 2017. The Proteins Degradation in Dry Cured Meat and Methods of Analysis: A REVIEW. The Journal of Microbiology, Biotechnology and Food Sciences, 7(2), 209. https://doi.org/10.15414/jmbfs.2017.7.2.209-220

Čuboň J., Haščík, P., Hleba, L., Cviková, P., Tkáčová, J., Lopašovský,L., Pavelková, A. 2019. Biogenic Amines as Risk Factors of Food Chain. Archives of Ecotoxicology. 1, (1), 7-10.

Dimitrov, D., Simov, Z., Dimitrov, Z., \& Ospanov, A. 2015. Improving of the microbiological and proteolytic profile of Kashkaval cheese by modification in heat treatments of cow's milk and Cheddared curd. The Journal of Microbiology, Biotechnology and Food Sciences, 4(6), 546. https://doi.org/10.15414/jmbfs.2015.4.6.546-549

Everard, C. D., O'callaghan, D. J., Howard, T. V., O'donnell, C. P., Sheehan, E. M., \& Delahunty, C. M. 2006. Relationships between sensory and rheological measurements of texture in maturing commercial cheddar cheese over a range of moisture and $\mathrm{pH}$ at the points of manufacture. Journal of Texture Studies, 37(4), 361-382. https://doi.org/10.1111/j.1745-4603.2006.00057.x

Flasarová, R., Pachlová, V., Buňková, L., Menšíková, A., Georgová, N., Dráb, V., \& Buňka, F. 2016. Biogenic amine production by Lactococcus lactis subsp. cremoris strains in the model system of Dutch-type cheese. Food chemistry, 194 68-75. https://doi.org/10.1016/j.foodchem.2015.07.069

Floury, J., Camier, B., Rousseau, F., Lopez, C., Tissier, J. P., \& Famelart, M. H. 2009. Reducing salt level in food: Part 1 . Factors affecting the manufacture of model cheese systems and their structure-texture relationships. LWT-Food Science and Technology, 42(10), 1611-1620. https://doi.org/10.1016/j.lwt.2009.05.026

Forde, A., \& Fitzgerald, G. F. 2000. Biotechnological approaches to the understanding and improvement of mature cheese flavour. Current Opinion in Biotechnology, 11(5), 484-489. https://doi.org/10.1016/s0958-1669(00)00130-0 Iurlina, M. O., \& Fritz, R. 2004. Microbiological quality of Port Salut Argentino cheese stored at two temperature treatments. LWT-Food Science and Technology, 37(7), 739-748. https://doi.org/10.1016/j.lwt.2004.02.011

Jimenez-Maroto, L. A., Lopez-Hernandez, A., Borneman, D. L., \& Rankin, S. A. 2016. A comparison of fresh, pasta filata, and aged Hispanic cheese using sensory, chemical, functional, and microbiological assessments. Journal of dairy science, 99(4), 2680-2693. https://doi.org/10.3168/jds.2015-10112

Kirmaci, H. A. 2016. Effect of wild strains used as starter cultures on free fatty acid profile of Urfa cheese. Polish Journal of Food and Nutrition Sciences, 66(4), 303-310. https://doi.org/10.1515/pjfns-2015-0034 
Komprda, T., Smělá, D., Novická, K., Kalhotka, L., Šustová, K., \& Pechová, P. 2007. Content and distribution of biogenic amines in Dutch-type hard cheese.

Food chemistry, 102(1), 129-137.

https://doi.org/10.1016/j.foodchem.2006.04.041

Lide I., David R. 2007. Platinum. CRC handbook of chemistry and physics, 4th edn. CRC Press, New York. 2608 pp. ISBN 0-8493-0487-3. https://doi.org/10.1021/ja069813z

Linares, D. M., Martín, M., Ladero, V., Alvarez, M. A., \& Fernández, M. (2011). Biogenic amines in dairy products. Critical reviews in food science and nutrition, 51(7), 691-703. https://doi.org/10.1080/10408398.2011.582813

Nair, V., O'Neil, C. L., \& Wang, P. G. 2008. Malondialdehyde. Encyclopedia of reagents for organic synthesis. Retrieved Feb, 26, 2009.

https://doi.org/10.1002/047084289x.rm013.pub2

Nedomová, Š., Kilián, L., Pytel, R., \& Kumbár, V. (2017). Effect of ripening time on colour and texture properties in cheese. Potravinarstvo, Slovak Journal of Food Sciences, 11(1), 296-301. https://doi.org/10.5219/744

Pachlová, V., Buňka, F., Buňková, L., Weiserová, E., Budínský, P., Žaludek, M., \& Kráčmar, S. 2011. The effect of three different ripening/storage conditions on the distribution of selected parameters in individual parts of Dutch-type cheese. International Journal of Food Science \& Technology, 46(1), 101-108. https://doi.org/10.1111/j.1365-2621.2010.02460.x

Pachlová, V., Salek, R. N., Buňka, F., \& Buňková, L. 2013. Changes of biogenic amine content and other selected parametres in white cheese model matrix. The Journal of Microbiology, Biotechnology and Food Sciences, 2 (1), 1175 -1184.

Pachlová, V., Buňková, L., Flasarová, R., Salek, R. N., Dlabajová, A., Butor, I. \& Buňka, F. 2018. Biogenic amine production by nonstarter strains of Lactobacillus curvatus and Lactobacillus paracasei in the model system of Dutch-type cheese. $L W T, 97,730-735$.

https://doi.org/10.1016/j.lwt.2018.07.045

Regulation (EU) No 1151/2012 of the European Parliament and of the Council of 21 November 2012 on quality schemes for agricultural products and foodstuffs Romeih, E. A., Michaelidou, A., Biliaderis, C. G., \& Zerfiridis, G. K. 2002. Lowfat white-brined cheese made from bovine milk and two commercial fat mimetics: chemical, physical and sensory attributes. International Dairy Journal, 12(6), 525-540. https://doi.org/10.1016/s0958-6946(02)00043-2

Rosenberg, M., Wang, Z., Chuang, S. L., \& Shoemaker, C. F. (1995) Viscoelastic property changes in Cheddar cheese during ripening. Journal of Food Science, 60(3), 640-644. https://doi.org/10.1111/j.1365 2621.1995.tb09846.x

Ruiz-Capillas C., Jiménez-Colmenero F., 2004. Biogenic amines in meat and meat products. Crit. Rev. Food Sci. 44, 489-499. https://doi.org/10.1080/10408690490489341

Saint-Eve, A., Lauverjat, C., Magnan, C., Déléris, I., \& Souchon, I. 2009. Reducing salt and fat content: Impact of composition, texture and cognitive interactions on the perception of flavoured model cheese. Food chemistry, 116(1), 167-175.

https://doi.org/10.1016/j.foodchem.2009.02.027

SAS(2008) 9.3 Enhanced Logging Facilities, Cary, NC: SAS Institute Inc., 2008. Sihufe, G. A., Zorrilla, S. E., \& Rubiolo, A. C. 2010a. The influence of ripening temperature and sampling site on the proteolysis in Reggianito Argentino cheese. LWT-Food Science and Technology, 43(2), 247-253. https://doi.org/10.1016/j.1wt.2009.08.001

Sihufe, G. A., Zorrilla, S. E., Perotti, M. C., Wolf, I. V., Zalazar, C. A., Sabbag, N. G., ... \& Rubiolo, A. C. 2010b. Acceleration of cheese ripening at elevated temperature. An estimation of the optimal ripening time of a traditional Argentinean hard cheese. Food Chemistry, 119(1), 101-107. https://doi.org/10.1016/j.foodchem.2009.06.001

Skeie, S., \& Ardö, Y. 2000. Influence from raw milk flora on cheese ripening studied by different treatments of milk to model cheese. LWT-Food Science and Technology, 33(7), 499-505. https://doi.org/10.1006/fstl.2000.0700

Spano, G., Russo, P., Lonvaud-Funel, A., Lucas, P., Alexandre, H., Grandvalet, C., ... \& Rattray, F. 2010. Biogenic amines in fermented foods. European journal of clinical nutrition, 64, S95-S100. https://doi.org/10.1038/ejen.2010.218 